\title{
Peripheral PD1-positive CD4 T-Lymphocyte Count Can Predict Progression-free Survival in Patients With Non-small Cell Lung Cancer Receiving Immune Checkpoint Inhibitor
}

\author{
MINEHIKO INOMATA ${ }^{1}$, TOMONOBU KADO ${ }^{1}$, SEISUKE OKAZAWA ${ }^{1}$, SHINGO IMANISHI ${ }^{1}$, CHIHIRO TAKA $^{1}$, \\ KENTA KAMBARA ${ }^{1}$, TAKAHIRO HIRAI ${ }^{1}$, HIROAKI TANAKA $^{1}$, KOTARO TOKUI $^{1}$, KANA HAYASHI ${ }^{1}$, \\ TOSHIRO MIWA $^{1}$, RYUJI HAYASHI ${ }^{2}$, SHOKO MATSUI $^{1}$ and KAZUYUKI TOBE ${ }^{1}$ \\ ${ }^{1}$ First Department of Internal Medicine, Toyama University Hospital, Toyama, Japan; \\ ${ }^{2}$ Department of Medical Oncology, Toyama University Hospital, Toyama, Japan
}

\begin{abstract}
Background/Aim: Little information is available about the association between peripheral T-lymphocyte expression of programmed cell death protein 1 (PDI) and the efficacy of immune checkpoint inhibitor therapy in patients with non-small cell lung cancer (NSCLC). We analyzed the PDI and cytotoxic T-lymphocyte associated protein 4 (CTLA4) expression in peripheral blood $T$ lymphocytes of patients with NSCLC receiving immune checkpoint inhibitor therapy. Patients and Methods: Patients with NSCLC who were scheduled to receive treatment with immune checkpoint inhibitors were prospectively enrolled in this study between November 2017 and November 2018. Peripheral blood samples were obtained within 1 week before or after the initiation of treatment with an immune checkpoint inhibitor. Results: Flow cytometry was conducted in 19 patients. Patients were treated with nivolumab, pembrolizumab, or atezolizumab. The group with a high percentage of $\mathrm{PDI}^{+} \mathrm{CD}^{+}$-lymphocytes relative to the total $\mathrm{CD}^{+}$T-lymphocyte count had a longer progression-free survival [median=6.0 (95\% confidence interval=0.5-not estimated) months] than the group with a low percentage of $\mathrm{PDI}^{+} \mathrm{CD}^{+}$T-lymphocytes [median $=1.1$ (95\% confidence intervaI=0.4-5.0) months; $p=0.034$, log-rank test $]$. However, no significant associations were detected with the percentages of $\mathrm{CTLA4}^{+} \mathrm{CD}^{+}, \mathrm{PDI}^{+} \mathrm{CDS}^{+}$or $\mathrm{CTLA4} 4^{+} \mathrm{CD} 8^{+}$ T-lymphocytes in the peripheral blood. Conclusion: A high percentage of peripheral $\mathrm{CD}^{+} \mathrm{PDI}^{+}$T-lymphocytes was
\end{abstract}

Correspondence to: Minehiko Inomata, MD, Ph.D., First Department of Internal Medicine, Toyama University Hospital, Sugitani 2630, Toyama, 930-0194, Japan. Tel: +81 764347287, FAX: +81 764345025, e-mail: 9446-tym@umin.org

Key Words: CD4-positive T-lymphocyte, immune check point inhibitor, non-small cell lung cancer, programmed death 1 . associated with a longer progression-free survival in patients receiving treatment with an immune checkpoint inhibitor. The systemic immune system may have an influence on the efficacy of immune checkpoint inhibitor therapy in patients with NSCLC.

Systemic therapy is the standard therapeutic option of care for patients with metastatic non-small cell lung cancer (NSCLC). Recently, immune checkpoint inhibitors, including programmed cell death protein 1 (PD1) inhibitor and programmed death ligand 1 (PD-L1) inhibitor, were demonstrated to confer survival benefit as compared to standard chemotherapy in patients with NSCLC (1-4).

A previous clinical trial suggested that tumor expression of PD-L1, a ligand of PD1, is a predictive marker of the efficacy of immune check point inhibitor therapy in patients with non-squamous cell NSCLC. However, no such association has been observed in patients with squamous cell NSCLC, and even in patients with non-squamous cell NSCLC, the association is not straightforward (2).

Several authors have investigated tumor-infiltrating immune cells and reported that elevated percentages of $\mathrm{PD}^{+}{ }^{+} \mathrm{CD} 8^{+}$T-lymphocytes were associated with worse clinical outcomes in patients in the absence of immune checkpoint inhibitor therapy (5-8). In a clinical trial of atezolizumab, a PD-L1 inhibitor, conducted in patients with NSCLC, treatment with atezolizumab yielded a longer overall survival than that with docetaxel in the patient subset in which the tumor-infiltrating immune cells stained positively for PD-L1 (3). Daud et al. reported that in patients with melanoma treated with immune checkpoint inhibitors, expression of PD1 and cytotoxic T-lymphocyte associated protein 4 (CTLA4) in the tumor-infiltrating lymphocytes was associated with longer patient survival (9). Furthermore, there is increasing interest in the roles of peripheral blood Tlymphocytes, and an association has been reported between 
the percentage of certain lymphocyte populations, such as $\mathrm{PD}^{+}{ }^{+} \mathrm{CD} 4^{+} \mathrm{T}$-lymphocytes and clinical outcomes in patients with malignancy (10-14). However, it remains unclear how immunonophenotypes of T-lymphocytes might affect the clinical course in patients with NSCLC receiving immune checkpoint inhibitor therapy.

We hypothesized that the systemic immune environment may affect the treatment efficacy of immune checkpoint inhibitors and investigated the association between the expression of immunosuppressive molecules, PD1 and CTLA4, on peripheral blood T-lymphocytes and progressionfree survival (PFS) in patients with NSCLC receiving treatment.

\section{Patients and Methods}

Patients. Patients with NSCLC were prospectively enrolled between November 2017 and November 2018. The inclusion criteria were as follows: i) Patients with cytologically or histologically confirmed NSCLC; and ii) patients scheduled to receive treatment with immune checkpoint inhibitors. Patients who were unwilling to provide informed consent for participation in the study were excluded.

The present study was conducted with the approval of the Ethics Committee, University of Toyama (approval number: 29-48), after obtaining written informed consent from each of the participants, in accordance with Ethical Guidelines for Medical and Health Research Involving Human Subjects (Ministry of Health, Labour and Welfare, Japan).

Treatment and clinical examination. Patients were treated with a PD1 or PD-L1 inhibitor, including nivolumab, pembrolizumab, or atezolizumab. These treatment and clinical examinations were all undertaken based on clinical judgment. The tumor PD-L1 expression was evaluated by immunohistochemistry using $22 \mathrm{C} 3$ antibody.

Disease progression was determined based on the physician's clinical judgment and RECIST version 1.1 (15). However, transient tumor enlargement was not considered disease progression. The response rate was calculated as the proportion of patients showing complete response or partial response in accordance with RECIST version 1.1.; no response confirmation was required for this analysis performed in this study.

Flow cytometry and cytokine testing. Peripheral blood samples from the patients were obtained within 1 week before or after the initiation of treatment with an immune checkpoint inhibitor. The antibodies used for this study were: anti-CD3-fluorescein isothiocyanate (clone HIT3a), anti-CD4-allophycocyanin/Cy7 (clone A161A1), anti-CD8-APC (clone Sk1), anti-PD1 (CD279)phycoerythrin/Cy7 (clone EH12. 2H7), and anti-CD152 (CTLA4)PE (clone 13D3), all purchased from BioLegend (San Diego, CA, USA). The stained cells were analyzed by flow cytometry on BD FACSAria SORP (BD Biosciences, New York, NY, USA).

We conducted an exploratory investigation of the association between the treatment efficacy and the peripheral plasma levels of cytokines, including those of vascular endothelial growth factor (VEGF) and tumor necrosis factor-alpha (TNF $\alpha)$. The cytokine testing was commissioned to SRL, Inc (Tokyo, Japan).
Statistical analysis. JMP version 11. 2. 0 (SAS Institute, Cary, NC, USA). was used for the statistical analysis. The primary endpoint was the PFS after the initiation of immune checkpoint inhibitor therapy. PFS was calculated from the date of initiation of treatment to the date of documentation of disease progression or death, and censored at the last visit until which no disease progression was observed. Patients were divided into two groups according to the median value of each parameter, and the PFS was compared between the two groups by the log-rank test. The response rate was compared by Fisher's exact test.

\section{Results}

Patient characteristics. Table I shows the patient characteristics. A total of 22 patients were included in the study, and 5, 11, and 6 patients were treated with nivolumab, pembrolizumab, and atezolizumab, respectively. Peripheral blood samples were obtained from all 22 patients. In 17 patients, they were obtained after the initiation of treatment with immune checkpoint inhibitor. Flow-cytometric analysis was conducted in 19 patients, and cytokine testing was conducted in 18 patients.

Survival and tumor response. Figure 1 shows the KaplanMeier curves for the 22 patients. The median PFS was 3.5 months (95\% CI=1.1-6.8 months). Disease progression or death occurred in 16 patients, and the disease progression was reconfirmed by repeat computed tomography in 14 patients. In patients with non-squamous cell NSCLC, patients with tumor PD-L1 expression of at least $50 \%$ had a longer PFS (PD-L1 50\% vs. <50\%: median= 4.3 months vs. 3.1 months, $p=0.118$ ), but it did not reach statistical significance.

Figure 2 shows the association between the expression of immunosuppressive molecules on peripheral blood $\mathrm{T}$ lymphocytes and PFS. Patients were divided into high or low groups by the median percentage of $\mathrm{PD}^{+}$or $\mathrm{CTLA} 4^{+}$cells relative to the total $\mathrm{CD}^{+}$or $\mathrm{CD}^{+}$cell count. The group with a high percentage of $\mathrm{PD} 1{ }^{+} \mathrm{CD} 4^{+}$T-lymphocytes had a longer PFS $[\geq 42 \%$ : median $=6.0$ (95\% CI=0.5-not estimated) months] than the group with a low percentage of such cells [<42\%: median=1.1 (95\% CI=0.4-5.0) months, $p=0.034]$. However, no significant associations of the PFS with the percentage of $\mathrm{CTLA} 4{ }^{+} \mathrm{CD} 4^{+}, \mathrm{PD}^{+} \mathrm{CD}^{+}$or $\mathrm{CTLA} 4^{+} \mathrm{CD} 8^{+}$ T-lymphocytes were detected. There was also no statistically significant association of the PFS with the plasma levels of VEGF ( $<80 v s . \geq 80 \mathrm{pg} / \mathrm{ml}:$ median=1.4 vs. 5.0 months, $p=0.490)$ nor TNF $\alpha(<2.0 v s . \geq 2.0 \mathrm{pg} / \mathrm{ml}$ : median=5.0 vs. 3.1 months, $p=0.581)$.

The tumor response rate was evaluated in 19 patients. The group with a high percentage of $\mathrm{PD} 1^{+} \mathrm{CD} 4^{+} \mathrm{T}$-lymphocytes $(5 / 10$ patients, $50 \%)$ showed a higher response rate than that with a low percentage of $\mathrm{PD} 1^{+} \mathrm{CD} 4^{+}$T-lymphocytes $(1 / 9$ patients, $11.1 \%$ ), although the difference was not statistically significant $(p=0.141)$. 
Table I. Patient characteristics $(n=22)$.

\begin{tabular}{llc}
\hline Age, years & Median (range) & $67.5(44-85)$ \\
Gender, n (\%) & Male & $17(77.3 \%)$ \\
Smoking history, n (\%) & Female & $5(22.7 \%)$ \\
& Yes & $19(86.4 \%)$ \\
PS, n (\%) & No & $3(13.6 \%)$ \\
& 0 & $8(36.4 \%)$ \\
Histology, n (\%) & $1-2$ & $14(63.6 \%)$ \\
& Non-squamous & $17(77.3 \%)$ \\
EGFR gene status, n (\%) & Squamous & $5(22.7 \%)$ \\
& Mutant & $4(18.2 \%)$ \\
Tumor PD-L1 expression, n (\%) & Wild-type/unknown & $18(81.8 \%)$ \\
& $<1 \%$ & $6(27.3 \%)$ \\
& $1-49 \%$ & $6(27.3 \%)$ \\
& $\geq 50 \%$ & $9(40.9 \%)$ \\
LDH, U/ml & Unknown & $1(4.5 \%)$ \\
NLR & Median (range) & $231(137-1,001)$ \\
CRP, mg/dl & Median (range) & $4.7(1.0-15.7)$ \\
& Median (range) & $1.5(0.2-12.6)$ \\
\hline
\end{tabular}

CRP: Serum C-reactive protein; EGFR: epidermal growth factor receptor; LDH: serum lactate dehydrogenase; NLR: neutrophil/ lymphocyte ratio; PD- L1: programmed death ligand 1; PS: performance status.

Association between PDI expression and other parameters. Table II shows the association between the percentage of $\mathrm{PD}^{+}{ }^{+} \mathrm{CD} 4^{+}$T-lymphocytes and other parameters. No significant association was observed between the percentage of the $\mathrm{PD} 1^{+} \mathrm{CD} 4^{+}$T-lymphocytes and any of the clinical parameters examined. There was no significant relationship between the plasma cytokine levels and the counts of $\mathrm{PD} 1^{+} \mathrm{CD} 4^{+}$T-lymphocytes, although the group with a high percentage of $\mathrm{PD}^{+} \mathrm{CD} 4^{+}$T-lymphocytes had relatively higher median plasma levels of TNF $\alpha$ ( $p=0.056$, Wilcoxon's rank-sum test).

\section{Discussion}

The present study showed a statistically significant association of high percentage of $\mathrm{CD} 4^{+} \mathrm{PD} 1^{+} \mathrm{T}-1 \mathrm{ymphocytes}$ in the peripheral blood with a longer PFS in patients with NSCLC receiving immune checkpoint inhibitor therapy, while no such association of PFS was observed with the percentage of $\mathrm{CTLA} 4{ }^{+} \mathrm{CD} 4^{+}, \mathrm{PD}^{+} \mathrm{CD} 8^{+}$or $\mathrm{CTLA} 4{ }^{+} \mathrm{CD} 8^{+}$ T-lymphocytes, nor with the plasma levels of cytokines, including those of TNF $\alpha$ and VEGF.

Possible associations between peripheral blood $\mathrm{T}$ lymphocyte counts and the efficacy of treatment with immune checkpoint inhibitors have been investigated by several authors. Some of the studies showed an increase in the percentages of $\mathrm{PD}^{+} \mathrm{Ki} 67^{+} \mathrm{CD}^{+}$T-lymphocytes following treatment with immune checkpoint inhibitors and reported that the treatment efficacy was associated with the

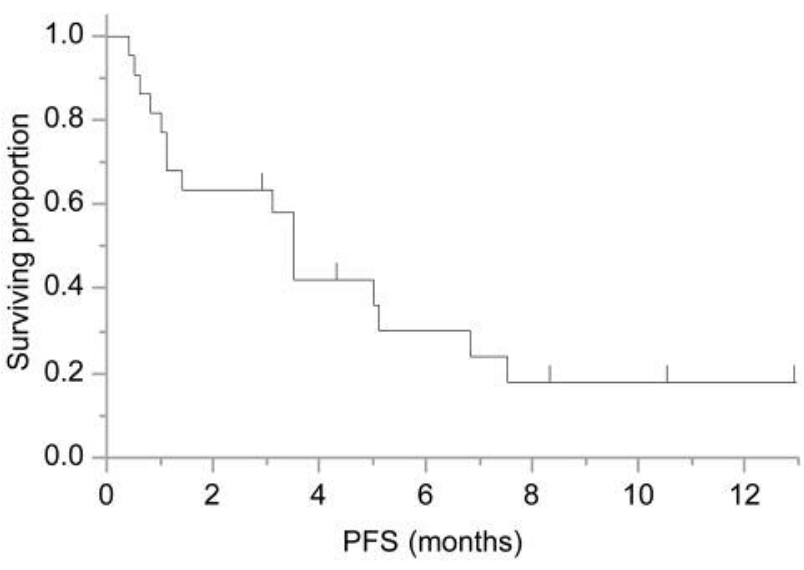

Figure 1. Kaplan-Meier curve for progression-free survival (PFS) in 22 patients with non-small cell lung cancer receiving immune checkpoint inhibitor therapy.

percentage of $\mathrm{PD}^{+} \mathrm{Ki} 67^{+} \mathrm{CD}^{+}$T-lymphocytes or the $\mathrm{PD}^{+} \mathrm{Ki}^{+} 7^{+} \mathrm{CD}^{+} \mathrm{T}$-lymphocyte/tumor burden ratio $(13,14)$.

Although no increase in the percentage of $\mathrm{Ki}-67^{+} \mathrm{CD} 4^{+} \mathrm{T}-$ lymphocytes was evident either before or after the initiation of treatment (13), the percentage of $\mathrm{PD}^{+} \mathrm{CD} 4^{+} \mathrm{T}$ lymphocytes has been reported to be associated with survival in patients with NSCLC receiving vaccine therapy (11) and patients with prostate cancer receiving immune therapy, including CTLA4 antibody ipilimumab (12).

Expression of PD1 is one of the mechanisms of Tlymphocyte exhaustion. This is supported by the observed reduction in cytokine production by tumor-infiltrating immune cells with expression of PD1 or CTLA4 $(9,16)$. However, peripheral PD $1^{+}$T-lymphocytes might not entirely represent an exhausted phenotype. T-Follicular helper cells, peripheral helper T-cells, and effector memory $\mathrm{T}$ lymphocytes are also known to express PD1. T-Follicular helper cells are considered to be $\mathrm{CD} 4^{+} \mathrm{T}$-cells that express C-X-C motif chemokine receptor 5 (CXCR5) and PD1, which facilitate the differentiation of B-cells into antibodysecreting cells and are associated with immunodeficiency, autoimmune diseases, and T-cell malignancies (17). Peripheral helper T-cells were reported to represent an expanded population of $\mathrm{PD} 1{ }^{\mathrm{hi}} \mathrm{CXCR} 5^{-} \mathrm{CD} 4^{+} \mathrm{T}$-cells in the synovium of patients with rheumatoid arthritis. These cells have the ability to help B-cells and are not exhausted (18). Effector memory T-cells have the ability to produce cytokines in response to re-stimulation by an antigen (19). In healthy adult humans, PD1 has been shown to be dominantly expressed in peripheral blood C-C motif chemokine receptor 7 (CCR7) ${ }^{-}$CD45RA ${ }^{-}$effector memory T-cells, suggesting that PD1 is not a marker of exhausted cells (20). Waki et al. reported that the majority of 

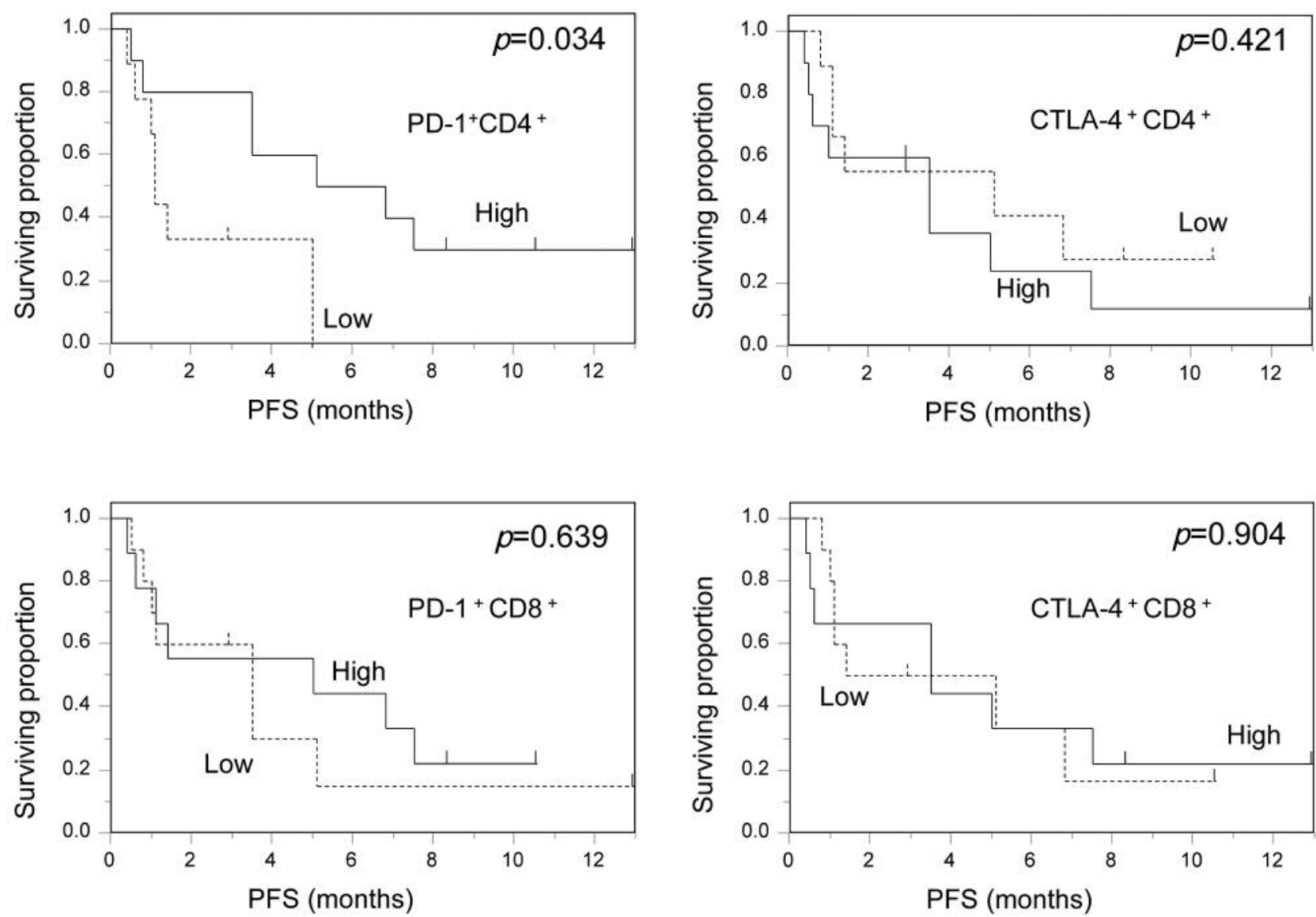

Figure 2. Kaplan-Meier curve for progression-free survival (PFS) in each group of patients divided according to the median programmed cell death protein $1(P D 1)^{+}$or cytotoxic T-lymphocyte associated protein $4(C T L A 4)^{+}$cell count relative to the total $C D 4^{+}$or $C D 8^{+}$cell count. $p$-Values were derived from log-rank tests.

$\mathrm{PD} 1^{+} \mathrm{CD} 4^{+}$and $\mathrm{CD} 8^{+} \mathrm{T}$-lymphocytes in the peripheral blood represented the $\mathrm{CCR}^{-} \mathrm{CD} 45 \mathrm{RA}^{-}$effector memory phenotype in patients with NSCLC (11). Furthermore, Broderick et al. showed that the antitumor effect of interleukin-12 was dependent on $\mathrm{CD}^{+}$cells, and the cell population displayed a phenotype consistent with that of effector memory T-cells (21). Based on these previous reports, the peripheral blood $\mathrm{PD} 1^{+} \mathrm{CD} 4^{+} \mathrm{T}$-lymphocytes in this study may not represent exhausted cells.

We did not find any significant association between the $\mathrm{PD} 1{ }^{+} \mathrm{CD} 4$ T-lymphocytes and any of the clinical parameters, including the serum levels of lactate dehydrogenase and C-reactive protein, nor the neutrophil/lymphocyte ratio, which have been reported to be associated with the survival in patients treated with immune checkpoint inhibitors (22-25). Therefore, it would seem that the clinical background characteristics did not differ significantly between the patient groups and that the mechanisms underlying the association between the percentage of $\mathrm{PD} 1^{+} \mathrm{CD} 4^{+} \mathrm{T}$-lymphocytes and the efficacy of immune checkpoint inhibitor therapy are independent of these clinical parameters.

There were some limitations in our study. Firstly, because of the small sample size, the effects of confounding factors cannot be entirely excluded. Secondly, because we conducted multiple statistical testing (log-rank test) by dividing the patients based on several parameters, multiplicity issues might have arisen. Thirdly, as it was permitted to obtain blood samples within 1 week of initiation of the immune checkpoint inhibitor therapy, the possibility that the elevated percentage of $\mathrm{PD} 1{ }^{+} \mathrm{CD} 4^{+} \mathrm{T}$-lymphocytes was caused by the immune checkpoint inhibitor and was not a baseline characteristic cannot be excluded. However, the percentage of $\mathrm{Ki}-67^{+} \mathrm{CD} 4^{+} \mathrm{T}$-lymphocytes has not been shown to increase after the start of immune checkpoint inhibitor therapy (13). 
Table II. Association between frequency of programmed cell death protein $1(P D 1)^{+} C D 4^{+}$T-lymphocytes and other parameters.

\begin{tabular}{|c|c|c|c|c|}
\hline & & \multicolumn{2}{|c|}{ PD1+CD4+ T-Lymphocytes } & \multirow{2}{*}{$p$-Value } \\
\hline & & Low & High & \\
\hline \multirow[t]{2}{*}{ Age, years } & $<68$ & $4(44.4 \%)$ & $4(40.0 \%)$ & $>0.99$ \\
\hline & $\geq 68$ & $5(55.6 \%)$ & $6(60.0 \%)$ & \\
\hline \multirow[t]{2}{*}{ Gender, n (\%) } & Male & $7(77.8 \%)$ & $7(70.0 \%)$ & $>0.99$ \\
\hline & Female & $2(22.2 \%)$ & $3(30.0 \%)$ & \\
\hline \multirow[t]{2}{*}{ Smoking history, n (\%) } & Yes & $8(88.9 \%)$ & $8(80.0 \%)$ & $>0.99$ \\
\hline & No & $1(11.1 \%)$ & $2(20.0 \%)$ & \\
\hline \multirow{2}{*}{ PS, n (\%) } & 0 & $3(33.3 \%)$ & $4(40.0 \%)$ & $>0.99$ \\
\hline & $1-2$ & $6(66.7 \%)$ & $6(60.0 \%)$ & \\
\hline \multirow[t]{2}{*}{ Histology, n (\%) } & Non-squamous & $6(66.7 \%)$ & $8(80.0 \%)$ & 0.629 \\
\hline & Squamous & $3(33.3 \%)$ & $2(20.0 \%)$ & \\
\hline \multirow[t]{2}{*}{$E G F R$ gene status, $\mathrm{n}(\%)$} & Mutant & $2(22.2 \%)$ & $2(20.0 \%)$ & $>0.99$ \\
\hline & Wild-type/unknown & $7(77.8 \%)$ & $8(80.0 \%)$ & \\
\hline \multirow[t]{2}{*}{ Tumor PD-L1 expression, $\mathrm{n}(\%)$} & $<50 \%$ & $6(75.0 \%)$ & $4(40.0 \%)$ & 0.188 \\
\hline & $\geq 50 \%$ & $2(25.0 \%)$ & $6(60.0 \%)$ & \\
\hline $\mathrm{LDH}, \mathrm{U} / \mathrm{ml}$ & Median (range) & $231(162-1,001)$ & $237(137-765)$ & 0.902 \\
\hline NLR & Median (range) & $5.6(1.1-10.5)$ & $4.6(1.0-15.7)$ & 0.683 \\
\hline $\mathrm{CRP}, \mathrm{mg} / \mathrm{dl}$ & Median (range) & $1.4(0.2-11.1)$ & $2.3(0.3-9.0)$ & 0.540 \\
\hline VEGF, pg/ml & Median (range) & $66.5(0-291)$ & $66.0(25-684)$ & 0.685 \\
\hline $\mathrm{TNF} \alpha, \mathrm{pg} / \mathrm{ml}$ & Median (range) & $1.7(1.2-2.2)$ & $2.2(1.8-8.8)$ & 0.056 \\
\hline
\end{tabular}

CRP: Serum C-reactive protein; EGFR: epidermal growth factor receptor; LDH: serum lactate dehydrogenase; NLR: neutrophil/lymphocyte ratio; PD- L1: programmed death ligand 1; PS: performance status; TNF $\alpha$ : tumor necrosis factor; VEGF, vascular endothelial growth factor.

\section{Conclusion}

In conclusion, the present study showed that the percentage of CD4+PD1+ T-lymphocytes in the peripheral blood was positively associated with PFS after the initiation of immune checkpoint inhibitor therapy, suggesting that the systemic immune system may have an influence on the clinical course in patients with NSCLC receiving immune checkpoint inhibitor therapy. Further investigations are needed to validate the results of this study.

\section{Conflicts of Interest}

The Authors declare that they have no competing interests.

\section{Authors' Contributions}

Minehiko Inomata contributed to the conception and design of the work, analysis, interpretation of data, and drafted the work. Tomonobu Kado contributed to the flow cytometric analysis and revision of the article. Seisuke Okazawa, Shingo Imanishi, Chihiro Taka, Kenta Kambara, Takahiro Hirai, Hiroaki Tanaka, Kotaro Tokui, Kana Hayashi, Toshiro Miwa, Ryuji Hayashi, Shoko Matsui contributed to enrollment of patients (data acquisition). Kazuyuki Tobe contributed to the interpretation of the data and revision of the article.

\section{Acknowledgements}

This work was supported by Novartis Pharma K.K., Nippon Boehringer Ingelheim Co., and Tamura Science and Technology Foundation.

\section{References}

1 Brahmer J, Reckamp KL, Baas P, Crinò L, Eberhardt WE, Poddubskaya E, Antonia S, Pluzanski A, Vokes EE, Holgado E, Waterhouse D, Ready N, Gainor J, Arén Frontera O, Havel L, Steins M, Garassino MC, Aerts JG, Domine M, Paz-Ares L, Reck M, Baudelet C, Harbison CT, Lestini B and Spigel DR: Nivolumab versus docetaxel in advanced squamous-cell nonsmall-cell lung cancer. N Engl J Med 373(2): 123-135, 2015. PMID: 26028407. DOI: 10.1056/NEJMoa1504627

2 Borghaei H, Paz-Ares L, Horn L, Spigel DR, Steins M, Ready NE, Chow LQ, Vokes EE, Felip E, Holgado E, Barlesi F, Kohlhäufl M, Arrieta $\mathrm{O}$, Burgio MA, Fayette J, Lena H, Poddubskaya E, Gerber DE, Gettinger SN, Rudin CM, Rizvi N, Crinò L, Blumenschein GR Jr., Antonia SJ, Dorange C, Harbison $\mathrm{CT}$, Graf Finckenstein $\mathrm{F}$ and Brahmer JR: Nivolumab versus docetaxel in advanced nonsquamous non-small-cell lung cancer. N Engl J Med 373(17): 1627-1639, 2015. PMID: 26412456. DOI: 10.1056/NEJMoa1507643.

3 Rittmeyer A, Barlesi F, Waterkamp D, Park K, Ciardiello F, von Pawel J, Gadgeel SM, Hida T, Kowalski DM, Dols MC, Cortinovis DL, Leach J, Polikoff J, Barrios C, Kabbinavar F, 
Frontera OA, De Marinis F, Turna H, Lee JS, Ballinger M, Kowanetz M, He P, Chen DS, Sandler A, Gandara DR and OAK Study Group: Atezolizumab versus docetaxel in patients with previously treated non-small-cell lung cancer (OAK): A phase 3 , open-label, multicentre randomised controlled trial. Lancet 389(10066): 255-265, 2017. PMID: 27979383. DOI: 10.1016/ S0140-6736(16)32517-X

4 Gandhi L, Rodríguez-Abreu D, Gadgeel S, Esteban E, Felip E, De Angelis F, Domine M, Clingan P, Hochmair MJ, Powell SF, Cheng SY, Bischoff HG, Peled N, Grossi F, Jennens RR, Reck M, Hui R, Garon EB, Boyer M, Rubio-Viqueira B, Novello S, Kurata T, Gray JE, Vida J, Wei Z, Yang J, Raftopoulos H, Pietanza MC, Garassino MC and KEYNOTE189 Investigators: Pembrolizumab plus chemotherapy in metastatic non-small-cell lung cancer. N Engl J Med 378(22): 2078-2092, 2018. PMID: 29658856. DOI: 10.1056/ NEJMoa1801005

5 Thompson RH, Dong H, Lohse CM, Leibovich BC, Blute ML, Cheville JC and Kwon ED: PD-1 is expressed by tumorinfiltrating immune cells and is associated with poor outcome for patients with renal cell carcinoma. Clin Cancer Res 13(6): 1757-1761, 2017. PMID: 17363529.

6 Sun S, Fei X, Mao Y, Wang X, Garfield DH, Huang O, Wang J, Yuan F, Sun L, Yu Q, Jin X, Wang J and Shen K: PD-1(+) immune cell infiltration inversely correlates with survival of operable breast cancer patients. Cancer Immunol Immunother 63(4): 395-406, 2014. PMID: 24514954.

7 Muenst S, Soysal SD, Gao F, Obermann EC, Oertli D and Gillanders WE: The presence of programmed death 1 (PD-1)positive tumor-infiltrating lymphocytes is associated with poor prognosis in human breast cancer. Breast Cancer Res Treat 139(3): 667-676, 2013. PMID: 23756627. DOI: 10.1007/s10549013-2581-3

8 Hsu MC, Hsiao JR, Chang KC, Wu YH, Su IJ, Jin YT and Chang Y: Increase of programmed death-1-expressing intratumoral CD8 T-cells predicts a poor prognosis for nasopharyngeal carcinoma. Mod Pathol 23(10): 1393-1403, 2010. PMID: 20657553. DOI: 10.1038/modpathol.2010.130

9 Daud AI, Loo K, Pauli ML, Sanchez-Rodriguez R, Sandoval PM, Taravati K, Tsai K, Nosrati A, Nardo L, Alvarado MD, Algazi AP, Pampaloni MH, Lobach IV, Hwang J, Pierce RH, Gratz IK, Krummel MF and Rosenblum MD: Tumor immune profiling predicts response to anti-PD-1 therapy in human melanoma. J Clin Invest 126(9): 3447-3452, 2016. PMID: 27525433. DOI: $10.1172 / \mathrm{JCI} 87324$

10 Dronca RS, Liu X, Harrington SM, Chen L, Cao S, Kottschade LA, McWilliams RR, Block MS, Nevala WK, Thompson MA, Mansfield AS, Park SS, Markovic SN and Dong H: T-Cell BIM levels reflect responses to anti-PD-1 cancer therapy. JCI Insight 1(6): pii: e86014, 2016. PMID: 27182556.

11 Waki K, Yamada T, Yoshiyama K, Terazaki Y, Sakamoto S, Matsueda S, Komatsu N, Sugawara S, Takamori S, Itoh K and Yamada A: PD-1 expression on peripheral blood T-cell subsets correlates with prognosis in non-small cell lung cancer. Cancer Sci 105(10): 1229-1235, 2014. PMID: 25117757. DOI: $10.1111 /$ cas. 12502

12 Santegoets SJ, Stam AG, Lougheed SM, Gall H, Scholten PE, Reijm M, Jooss K, Sacks N, Hege K, Lowy I, Cuillerot JM, von Blomberg BM, Scheper RJ, van den Eertwegh AJ, Gerritsen WR and de Gruijl TD: T-Cell profiling reveals high CD4 ${ }^{+}$CTLA- $4^{+}$
T-cell frequency as dominant predictor for survival after prostate GVAX/ipilimumab treatment. Cancer Immunol Immunother 62(2): 245-256, 2013. PMID: 22878899. DOI: 10.1007/s00262012-1330-5

13 Kamphorst AO, Pillai RN, Yang S, Nasti TH, Akondy RS, Wieland A, Sica GL, Yu K, Koenig L, Patel NT, Behera M, Wu H, McCausland M, Chen Z, Zhang C, Khuri FR, Owonikoko TK, Ahmed R and Ramalingam SS: Proliferation of PD-1+ CD8 T-cells in peripheral blood after PD-1-targeted therapy in lung cancer patients. Proc Natl Acad Sci USA 114(19): 4993-4998, 2017. PMID: 28446615. DOI: 10.1073/pnas.1705327114

14 Huang AC, Postow MA, Orlowski RJ, Mick R, Bengsch B, Manne S, Xu W, Harmon S, Giles JR, Wenz B, Adamow M, Kuk D, Panageas KS, Carrera C, Wong P, Quagliarello F, Wubbenhorst B, D'Andrea K, Pauken KE, Herati RS, Staupe RP, Schenkel JM, McGettigan S, Kothari S, George SM, Vonderheide RH, Amaravadi RK, Karakousis GC, Schuchter LM, Xu X, Nathanson KL, Wolchok JD, Gangadhar TC and Wherry EJ: T-cell invigoration to tumour burden ratio associated with anti-PD-1 response. Nature 545(7652): 60-65, 2017. PMID: 28397821. DOI: 10.1038/nature22079

15 Eisenhauer EA, Therasse P, Bogaerts J, Schwartz LH, Sargent D, Ford R, Dancey J, Arbuck S, Gwyther S, Mooney M, Rubinstein L, Shankar L, Dodd L, Kaplan R, Lacombe D and Verweij J: New response evaluation criteria in solid tumours: revised RECIST guideline (version 1.1). Eur J Cancer 45(2): 228-247, 2009. PMID: 19097774. DOI: 10.1016/j.ejca.2008.10.026

16 Zhang Y, Huang S, Gong D, Qin Y and Shen Q: Programmed death-1 upregulation is correlated with dysfunction of tumorinfiltrating CD8+ T-lymphocytes in human non-small cell lung cancer. Cell Mol Immunol 7(5): 389-395, 2010. PMID: 20514052. DOI: $10.1038 / \mathrm{cmi} .2010 .28$

17 Tangye SG, Ma CS, Brink R and Deenick EK: The good, the bad and the ugly - TFH cells in human health and disease. Nat Rev Immunol 13(6): 412-426, 2013. PMID: 23681096. DOI: $10.1038 /$ nri3447

18 Rao DA, Gurish MF, Marshall JL, Slowikowski K, Fonseka CY, Liu Y, Donlin LT, Henderson LA, Wei K, Mizoguchi F, Teslovich NC, Weinblatt ME, Massarotti EM, Coblyn JS, Helfgott SM, Lee YC, Todd DJ, Bykerk VP, Goodman SM, Pernis AB, Ivashkiv LB, Karlson EW, Nigrovic PA, Filer A, Buckley CD, Lederer JA, Raychaudhuri S and Brenner MB: Pathologically expanded peripheral T-helper cell subset drives B cells in rheumatoid arthritis. Nature 542(7639): 110-114, 2017. PMID: 28150777. DOI: 10.1038/nature20810

19 Lanzavecchia A and Sallusto F: Understanding the generation and function of memory T-cell subsets. Curr Opin Immunol 17(3): 326-332, 2005. PMID: 15886125.

20 Duraiswamy J, Ibegbu CC, Masopust D, Miller JD, Araki K, Doho GH, Tata P, Gupta S, Zilliox MJ, Nakaya HI, Pulendran B, Haining WN, Freeman GJ and Ahmed R: Phenotype, function, and gene expression profiles of programmed death-1(hi) CD8 Tcells in healthy human adults. J Immunol 186(7): 4200-4212, 2011. PMID: 21383243. DOI: 10.4049/jimmunol.1001783

21 Broderick L, Yokota SJ, Reineke J, Mathiowitz E, Stewart CC, Barcos M, Kelleher RJ Jr., Bankert RB: Human CD4+ effector memory T-cells persisting in the microenvironment of lung cancer xenografts are activated by local delivery of IL-12 to proliferate, produce IFN-gamma, and eradicate tumor cells. J Immunol 174: 898-906, 2005. PMID: 15634912. 
22 Taniguchi Y, Tamiya A, Isa SI, Nakahama K, Okishio K, Shiroyama T, Suzuki H, Inoue T, Tamiya M, Hirashima T, Imamura $\mathrm{F}$ and Atagi $\mathrm{S}$ : Predictive factors for poor progressionfree survival in patients with non-small cell lung cancer treated with nivolumab. Anticancer Res 37: 5857-5862, 2017. PMID: 28982912.

23 Oya Y, Yoshida T, Kuroda H, Mikubo M, Kondo C, Shimizu J, Horio Y, Sakao Y, Hida T and Yatabe Y: Predictive clinical parameters for the response of nivolumab in pretreated advanced non-small-cell lung cancer. Oncotarget 8: 103117-103128, 2017. PMID: 29262550. DOI: 10.18632/oncotarget.21602

24 Mezquita L, Auclin E, Ferrara R, Charrier M, Remon J, Planchard D, Ponce S, Ares LP, Leroy L, Audigier-Valette C, Felip E, Zerón-Medina J, Garrido P, Brosseau S, Zalcman G, Mazieres J, Caramela C, Lahmar J, Adam J, Chaput N, Soria JC and Besse B: Association of the lung immune prognostic index with immune checkpoint inhibitor outcomes in patients with advanced non-small cell lung cancer. JAMA Oncol 4: 351-357, 2018. PMID: 29327044. DOI: 10.1001/jamaoncol.2017.4771
25 Bagley SJ, Kothari S, Aggarwal C, Bauml JM, Alley EW, Evans TL, Kosteva JA, Ciunci CA, Gabriel PE, Thompson JC, Stonehouse-Lee S, Sherry VE, Gilbert E, Eaby-Sandy B, Mutale F, DiLullo G, Cohen RB, Vachani A and Langer CJ: Pretreatment neutrophil-to-lymphocyte ratio as a marker of outcomes in nivolumab-treated patients with advanced nonsmall-cell lung cancer. Lung Cancer 106: 1-7, 2017. PMID: 28285682. DOI: 10.1016/j.lungcan.2017.01.013

Received November 3, 2019

Revised November 8, 2019

Accepted November 11, 2019 